原著

\title{
上皮性卵巣腫瘍における Proliferating Cell Nuclear Antigen (PCNA) の免疫組織化学的検討
}

\author{
広島大学医学部産科婦人科学教室 ${ }^{11}$, 県立広島病院産婦人科 ${ }^{21}$ \\ 山中伸一郎1) 永井 宣隆 ${ }^{1)}$ 村上 隆浩1) 松田 博2) \\ 大濱 紘三1)
}

当科で手術を行った上皮性卵巣腫瘍 116 例を対象とし, そのホルマリン固定パラフィン包埋組織 切片を用いて, 増殖細胞マーカーとしての有用性が示唆されている proliferating cell nuclear antigen（PCNA）の発現をモノクローナル抗体 PC 10 (Novocastra 社)により免疫組織化学的 に検索した。

卵单腫瘍における平均 PCNA 標識率は, 悪性群 $33.0 \%$, 境界悪性群 $12.5 \%$, 良性群 $3.4 \%$ で 各群間に有意差が認められ, 病理組織学的に良性一境界悪性, 境界悪性一悪性の区別が難しい場合 の診断の一助になり得ると考えられた。

また悪性群における化学療法前後の平均標識率は $35.0 \%$ および $26.1 \%$ でこの間に有意差（p< 0.05）を認め, 化学療法の効果を細胞増殖能の低下として組織学的に判定することが可能と思われ た。

PCNA 標識率と核分裂数との間には相関係数 $0.57(\mathrm{p}<0.001)$ の有意な相関が認められ, PCNA 標識率が核分裂数と同様に腫瘍の組織学的覀性度の指標として有用であることが示唆され た.

Key words : Epithelial ovarian tumors_-Immunohistochemistry-Proliferating cell nuclear antigen (PCNA)—Mitotic activity

\section{I. 緒言}

PCNA (proliferating cell nuclear antigen) は,

\footnotetext{
Immunohistochemical study of proliferating cell nuclear antigen (PCNA) in epithelial ovarian tumors

Shinichiro YAMANAKA ${ }^{1)}$, M.D., Nobutaka NAGAI ${ }^{1)}$, M.

D., Takahiro MURAKAMI') M.D., Hiroshi MATSUDA ${ }^{2)}$, M.

D., Koso OHAMA ${ }^{1)}$, M.D.

${ }^{1)}$ Department of Obstetrics and Gynecology, School of Medicine, Hiroshima University

${ }^{2)}$ Hiroshima Prefectural Hospital

論文別刷請求先：画 734 広島市南区霞 1 の 2 の 広島大学

医学部産科婦人科学教室 山中伸一郎

平成 4 年 7 月 15 日受付

平成 4 年 10 月 30 日受理
}

DNA polymerase $\delta$ の補助蛋白質としてDNA 合成 に関与し，細胞の増殖サイクルの $\mathrm{G} 1$ 後期から $\mathrm{S}$ 期に かけて細胞核内に出現することから，增殖細胞マーカ 一としての有用性が示唆されている。 今回われわれ は，当科で手術を行った上皮性卵巣腫瘍 116 例につい て PCNAの発現を免疫組織化学的に検索するととも に核分裂数との関係も検討したのでその成績を報告す る。

\section{II. 対象および方法}

\section{1. 対象}

1981 年から 1991 年までの 11 年間に広島大学産婦 人科で手術を行った上皮性卵巣腫瘍 116 例（表 1 ）を 
表 1 対象症例

\begin{tabular}{|c|c|c|c|c|c|}
\hline & 例数 & 漿液性 & 粘液性 & 類内膜 & 明細胞 \\
\hline 悪性群 & 79 & 38 & 15 & 19 & 7 \\
\hline 化学療法前 & 61 & 25 & 14 & 17 & 5 \\
\hline 化学療法後 & 18 & 13 & 1 & 2 & 2 \\
\hline 境界悪性群 & 17 & 4 & 12 & 0 & 1 \\
\hline 良性群 & 20 & 10 & 10 & 0 & 0 \\
\hline 計 & 116 & 52 & 37 & 19 & 8 \\
\hline
\end{tabular}

対象として，10\%ホルマリンで24４8 時間固定され たパラフィン包埋組織切片を用いた。

\section{2. 方法}

PCNAの検出は, ABC 法により免疫組織化学的に 行った。すなわち上記ホルマリン固定パラフィン包埋 組織切片をキシレンにより脱パラフィンした後, $0.3 \% \mathrm{H}_{2} \mathrm{O}_{2}$ 加メ夕ノール液にて内因性ペルオキシダ ーゼ活性を阻止した。次に 5\% 正常ウマ血清で非特異 的染色を阻止した後，1次抗体としてマウス抗 PCNA モ)クローナル抗体（クローン PC 10, Novocastra 社) を用い，100 倍希䣋で $4^{\circ} \mathrm{C} 24$ 時間反応さ せた。次に 2 次抗体としてビオチン標識抗マウス IgG 抗体を加え 30 分間反応させた後, avidin-biotin peroxidase complex と 30 分間反応させた。最後に $\mathrm{H}_{2}$ $\mathrm{O}_{2}$-diaminobentizine (DAB) で発色させ, メチルグ リーンの counter staining を施した。また陰性コント ロールとして, 上記の 1 次抗体のかわりに正常マウス 血清を用いて $\mathrm{ABC}$ 法を行い，発色しないことを確認 した。次に上記染色標本を 400 倍で鏡検し, 腫瘍細胞 約 1000 個中に占める PCNA 陽性細胞数をカウント して症例ごとの陽性百分率 (標識率) を算出した. PCNA 陽性細胞判定基準を写真 1 に示した。

なお固定時間による PCNAの染色性の変化をみる 目的で, 漿液性腺癌組織を 3 分割し $10 \%$ ホルマリン で 4 時間，24 時間，48 時間固定して PCNA 免疫染 色を行い，染色性の相違を検討した。

また一部の悪性例については，100\%エタノールで 3 時間固定したタッチスメアについても同様に染色・ カウントし，組織標本と比較した。

さらにPCNA 免疫染色標本の連続切片に H-E 染 色を行い，腫瘍領域中核分裂像の最も多い部分で 400 倍連続 10 視野あたりの核分裂数（/10 HPF）を算出 し, PCNA 標識率との相関を検討した。この際明ら かな metaphaseを示す核分裂像だけを数え，また核 崩壊像と核濃縮像を除外した。

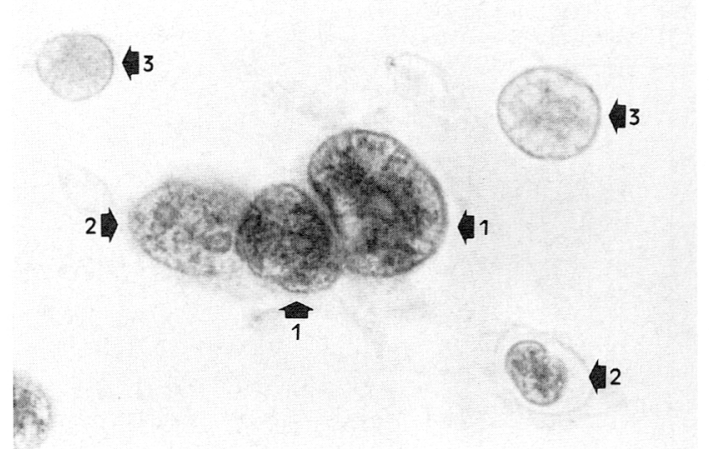

写真 1 PCNA 陽性細胞判定基準. 細胞核が濃染(矢印 1) 〜淡染（矢印 2) している細胞を陽性とし，まっ たく染色されていない細胞（矢印 3 ）のみを陰性 と判定した。陽性細胞では核が顆粒状〜びまん性 に染色されている（PCNA免疫染色，×1000）

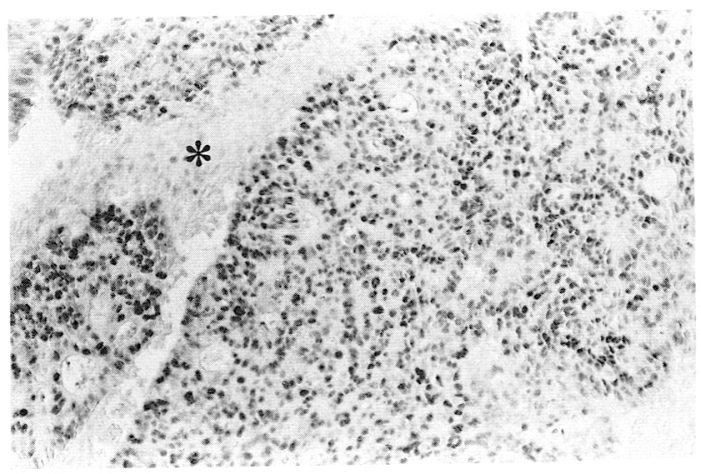

写真 2 粘液性腺癌. 間質部・壊死部 $(*)$ を除いては, 腫瘍細胞の核が明らかな局在傾向なくほぼ均一に 染色されている（PCNA 免疫染色， $\times 100 ）$

\section{III. 成 績}

組織標本上でのPCNA 陽性細胞の分布をみると, 壊死部分ではまったく染色されず，また間質部でもほ とんど染色されなかった以外は一定の局在傾向は認め られず，特に悪性群では腫瘍部分全体がびまん性に染 色されるものが多かった（写真 2 ).

$10 \%$ ホルマリンで 4 時間, 24 時間および 48 時間固 定した漿液性腺癌組織のPCNA 免疫染色像を写真 3 に示した。固定時間の差による明らかな PCNA 染色 性の変化は認められなかった。

上皮性卵巣腫瘍における PCNA 標識率を表 2 に示 した。平均標識率は, 悪性群 $33.0 \%$, 境界悪性群 


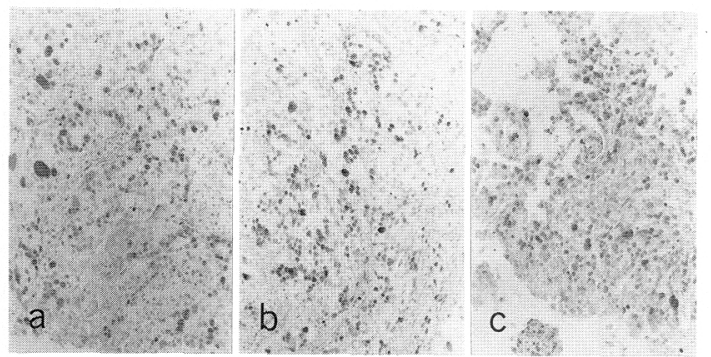

写真 3 漿液性腺癌。10\% ホルマリンで 4 時間(a)，24 時 間（b），48 時間（c）固定した標本の PCNA 免疫 染色像では，固定時間の差による明らかな染色性 の変化は認められない $($ PCNA 免疫染色, $\times 100)$

表 2 上皮性卵巣腫瘍における PCNA 標識率

\begin{tabular}{|c|c|c|}
\hline & 例数 & mean $\pm \mathrm{SD}(\%)$ \\
\hline 悪性群 & 79 & $33.0 \pm 16.2$ \\
\hline 化学療法前 & 61 & $35.0 \pm 16.6 \neg$ \\
\hline 化学療法後 & 18 & $26.1 \pm 12.8 \stackrel{* 2}{* 1} * 1$ \\
\hline 境界悪性群 & 17 & $12.5 \pm 7.5$ \\
\hline 良性群 & 20 & $3.4 \pm 4.6$ \\
\hline
\end{tabular}

$* 1: \mathrm{p}<0.001, * 2: \mathrm{p}<0.05$

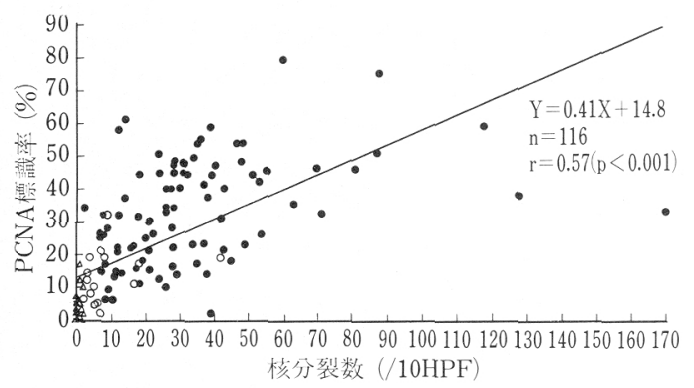

図 1 上皮性卵巣腫瘍に拈ける PCNA 標識率と核分裂数 との相関関係 $($ : 悪性例, $\bigcirc$ : 境界悪性例, $\triangle$ : 良性例)

$12.5 \%$ ，良性群 $3.4 \%$ でいずれの間にも有意差（ $\mathrm{p}<$ 0.001）を認めた。また亜性群を化学療法前と化学療 法後に分けると，平均標識率はそれぞれ $35.0 \%$, $26.1 \%$ で有意差 $(\mathrm{p}<0.05)$ が認められ, 化学療法に より細胞増殖能が低下することが示された。な扮化学 療法後の検体はいずれも 1985 年以降のもので, 化学 療法の regimen は CAP (CPM, ADM, CDDP) で あった。

またPCNA 標識率と核分裂数との間には, 図 1 の ごとく相関係数 $0.57(\mathrm{p}<0.001)$ の有意な相関がみ られた。
表 3 上皮性卵巣腫瘍悪性群の化学療法前症例 にお讨る組織型別 PCNA 標識率

\begin{tabular}{|c|c|c|}
\hline & 例数 & mean $\pm \mathrm{SD}(\%)$ \\
\hline 漿液性腺癌 & 25 & $26.6 \pm 14.4 \neg$ \\
\hline 粘液性腺癌 & 14 & $43.9 \pm 14.7 \stackrel{* 1}{\lrcorner}$ \\
\hline 類内膜腺癌 & 17 & $35.9 \pm 16.3$ \\
\hline 明細胞腺癌 & 5 & $48.7 \pm 6.9$ \\
\hline
\end{tabular}

$* 1: \mathrm{p}<0.001, * 2: \mathrm{p}<0.01$

表 4 上皮性卵单腫瘍覀性群の化学療法前症例 に扔ける進行期別 PCNA 標識率

\begin{tabular}{rrrrll}
\hline \hline & & 例数 & & mean $\pm \mathrm{SD}(\%)$ \\
\hline $\mathrm{I}$ & 期 & 20 & $34.9 \pm 13.8$ & \\
$\mathrm{II}$ & 期 & 8 & $33.5 \pm 9.7$ & \\
$\mathrm{III}$ & 期 & 27 & $33.2 \pm 18.6$ & \\
$\mathrm{IV}$ & 期 & 6 & $45.2 \pm 18.8$ & NS \\
\hline
\end{tabular}

NS : not significant

表 5 上皮性卵巣腫瘍悪性群の化学療法前症例 に扮ける分化度別 PCNA 標識率

\begin{tabular}{lrll}
\hline \hline & 例数 & mean $\pm \mathrm{SD}(\%)$ \\
\hline G1 (高分化) & 35 & $34.9 \pm 17.0$ & \\
G2 (中分化) & 20 & $33.7 \pm 17.0$ & \\
G3 (低分化) & 6 & $36.0 \pm 13.6$ & NS \\
\hline NS : not significant & &
\end{tabular}

次に上皮性卵巣腫瘍悪性群の化学療法前症例（61 例）について組織型, 臨床進行期抢よび組織分化度と PCNA 標識率との関係を検討した。組織型別の検討 では, 漿液性腺癌での PCNA 標識率が他の 3 型より 低々, 細胞増殖能が他に比べて低い傾向がみられた (表 3 )。臨床進行期別では, 各進行期間纪有意差はみ られなかったものの，I〜III期に比べIV期で高い傾向 にあった（表 4 ）。組織分化度別では，分化度の違い による標識率の有意な差は認められなかった（表 5 )。

また固定後経過した時間による PCNA 染色性の変 化を検討するため，化学療法前症例61例を 1981 1985 年の 5 年間の 26 例と 1986 1991 年の 6 年間の 35 例の 2 群に分け，おのおのの PCNA 染色性を検討 し，またPCNA 標識率の mean $\pm \mathrm{SD}$ を算出した。そ の結果 2 群間のPCNA 染色性に差はみられず，また PCNA 標識率の mean $\pm \mathrm{SD}$ は 1981 1985 年の 26 例 が $36.1 \pm 17.3 \% ， 1986 \sim 1991$ 年の 35 例が $33.4 \pm$ 15.4\%で2 群間に有意な差は認められなかった。

写真 4 亿漿液性腺癌例（PCNA 標識率 $26.2 \%$ ）の 


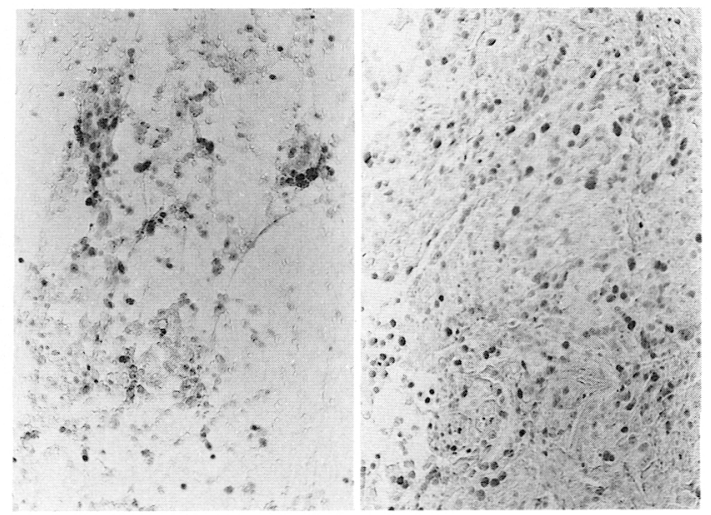

写真 4 漿液性腺癌. 夕ッチスメア（左）においても，組 織標本 (右) とほほ同様に染色されている(PCNA 免疫染色， × 100)

組織抢よびタッチスメアの PCNA 免疫染色像を示し た、タッチスメアにおいても組織標本とほ棌同様に染 色され，タッチスメアのPCNA 免疫染色によっても 細胞増殖能の検索が可能と考えられた。

\section{IV. 考察}

PCNA は，一部の全身性エリテマトーデス患者血 清中の抗核抗体が增殖細胞の核と特異的に反応するこ とから見出された蛋白質で4), 細胞周期が速く回転す る細胞ではその核内に多量に検出されることから cyclin とも呼ばれている1)。また，PCNA は細胞周期 の $\mathrm{G} 1$ 後期から $\mathrm{S}$ 期（DNA 合成期）にかけて細胞核 内に出現 ${ }^{5)}$, DNA polymerase $\delta$ の補助蛋白質とし て DNA 合成に重要な役割を果たしていることが判明 している゙2.

増殖細胞抗原に対する免疫組織化学染色用の抗体と して現在市販されている主なものに，Ki 67 抗体や抗 BrdU 抗体，抗 PCNA 抗体などがある.Ki 67 抗体は 凍結切片での染色は可能であるが，ホルマリン固定パ ラフィン包埋切片は使用できない。 また抗 BrdU 抗 体は，パラフィン包埋切片の染色はできるが, 前処置 として細胞内に BrdUを取り込ませておくことが必 要である。一方, 抗 PCNA 抗体はホルマリン固定パ ラフィン包埋切片で染色できるため retrospective な 検索が可能であり，また抗 BrdU 抗体のような前処 置も必要なく, 簡便で有用な増殖細胞マーカーであ る.

PCNA の細胞内での染色性については，抗 PCNA
抗体により細胞の核が染色され，核内では顆粒状のも のからびまん性のものまで，また濃いものから淡いも のまで認められたが，今回はこれらをいずれも陽性と 判定した (写真 1 参照). PCNA 陽性細胞の腫瘍組織 に扮ける分布については壊死部分ではまったく染色さ れず，また間質部でもほとんど染色されなかった以外 は一定の局在傾向は認められず，特に悪性群では腫瘍 部分全体がびまん性に染色されるものが多かった（写 真 2 参照)。これにより悪性群では壊死部分や間質部 を除く腫瘍部分の細胞増殖能がほぼ均一に六進してい るものが多いと考えられた。

PCNA と他の増殖細胞検索法との相関性を示す報 告としては, Ki 67 標識率と PCNA 標識率との間に $\mathrm{r}=0.76(\mathrm{p}<0.05)$ の相関を認めたとするもの7), PCNA 標識率とフローサイトメトリーによる増殖細 胞分画が泳济致することを示したもの ${ }^{3)}$, 固形悪性 腫場において PCNA 標識率が組織学的悪性度や核分 裂数に相関することを示したもの吕などがある.

今回のわれわれの検討でも，PCNA 標識率と核分 裂数との間には相関係数 $0.57(\mathrm{p}<0.001)$ の良好な 相関がみられ，PCNA が核分裂数と同様に腫瘍細胞 の増殖能の指標として有用であることが示唆された。

これまでに, 卵巣腫瘍における PCNA 発現を検索 した報告は少ない。澤田らつは，卵巣腫瘍のうち PCNA 標識率が $31 \%$ 以上であったのは, 良性群 0/5 (0\%), 境界悪性群 0/6(0\%), 悪性群 11/17(65\%) で あり，腫瘍の癌化とともに PCNA 標識率が上昇する ところから, PCNA は腫瘍の悪性度の指標として用 いうることを報告している。われわれの検討でも，上 皮性卵巣腫瘍に打汀了平均 PCNA 標識率は良性群 $3.4 \%$ ，境界悪性群 $12.5 \%$, 覀性群 $33.0 \%$ で，いず れの間にも有意な差が認められ, 病理組織学的に良性 一境界悪性，境界覀性一悪性の区別が難しい場合の診 断の一助になり得ると考えられた。

また悪性群において, 化学療法前に比へて化学療法 後で PCNA 標識率が有意に低值であったことより， 細胞増殖能の低下を指標とする化学療法効果の推定が ある程度可能と考えられた。

今後は PCNA 陽性細胞の判定基準および PCNA 標識率と長期予後との関連性などについてさらに検討 していきたい.

本論文の要旨は, 第 33 回日本臨床細胞学会総会（1992 年 6 月, 福岡) で発表した. 


\section{Summary}

We used an immunohistochemical technique to determine whether monoclonal antibody (PC 10) for proliferating cell nclear antigen (PCNA) could be useful as a marker of proliferating cells with formalin-fixed, paraffin-embedded tissue sections of 116 epithelial ovarian tumors. The mean labeling rate for PCNA was $33.0 \%$ in the malignant group (79 cases), $12.5 \%$ in the borderline-malignant group (17 cases) and $3.4 \%$ in the benign group (20 cases), showing significant differences among all groups. The mean labeling rate for PCNA in the malignant group was significantly higher, $35.0 \%$, in the prechemotherapy group (61 cases) than in the postchemotherapy group (18 cases : $26.1 \%$ ). These results suggest that the decrease in proliferating activity in the malignant cases with PCNA staining may be attributable to chemotherapy. Furthermore, there was a positive correlation $(r=0.57)$ between the labeling rate for PCNA and mitotic activity. These results suggest that PCNA is a useful marker for distinguishing malignant tumors and assessing mitotic activity.

\section{文 献}

1) Bravo, R., Fey, S.J., Bellatin, J., et al. : Identification of a nuclear and of a cytoplasmic polypeptide whose relative proportion are sensitive to changes in the rate of cell proliferation, Exp. Cell Res., $136: 311 \sim$ 319, 1981.

2) Bravo,. R., Frank, R., Blundell, P.A., et al. : Cyclin/ PCNA is the auxiliary protein of DNA polymerase delta, Nature, 326:515 517, 1987.

3) Garcia, R.L., Coltrera, M.D., Gown, A.M. : Analysis of proliferative grade using anti PCNA/cyclin monoclonal antibodies in fixed, embedded tissues, Am. J. Pathol., $4:$ 733 739, 1989.

4) Miyachi, K., Fritzler, M.J., Tan, E.M. : Autoantibody to a nuclear antigen in proliferating cells, J. Immunol., $121: 2228 \sim 2234,1978$.

5）守内哲也：PCNA/DNA ポリメラーゼ $\delta$ 補助蛋白質と その遺伝子，蛋白質核酸酵素，33：1179〜1185, 1988.

6) Robbins, B.A., de la Vega, D., Ogata, K., et al. : immunohistochemical detection of proliferating cell nuclear antigen in solid human malignancies, Arch. Pathol. Lab. Med., 111 : 841 845, 1987.

7）澤田益臣，上田外幸，井上正樹・他：婦人科腫瘍並びに 関連病変に括ける Proliferating Cell Nuclear Antigen (PCNA) の免疫組織学的検討, 日産婦誌, $44: 181$ 187, 1992. 